\title{
Sabdatama dan Sabdaraja Sri Sultan Hamengku Buwono X dalam Perspektif Keistimewaan Daerah Istimewa Yogyakarta
}

\author{
Raisa Rizani \\ Mahasiswa Fakultas Hukum Universitas Islam Indonesia \\ Jl. Taman Siswa No. 158 Yogyakarta \\ raisarizani@ymail.com
}

\begin{abstract}
The issue of Sabdatama and Sabdaraja by Sri Sultan Hamengku Buwono X has created pros and cons both from the internal parties and external of Kraton (Kingdom). This research is to study two issues: first, what is the juridical implication with the issues of Sabdatama and Sabdaraja towards Regulation No. 13 of 2012 about the Specialty of Special District of Yogyakarta (DIY)? Second, can Sabdatama and Sabdaraja be as a reference in revising the Law of Specialty? The research method used is the normative-juridical method with the historical approach and the regulation approach. The result of this research concluded: first, the substances of Sabdatama and Sabdaraja are contradicting with the Specialty Regulation of Special District of Yogyakarta and is not included in the hierarchy of law and regulation and not as a source of constitutional law. Second, Sabdatama and Sabdaraja are not suitable if used as a base to change the Law of Specialty of Special District of Yogyakarta.
\end{abstract}

Keyword: Sri Sultan Hamengku Buwono X, Law of Specialty of Special District of Yogyakarta (DIY), sabdatama, and sabdaraja

\begin{abstract}
Abstrak
Dikeluarkannya Sabdatama dan Sabdaraja oleh Sri Sultan Hamengku Buwono X menimbulkan pro dan kontra baik dari kalangan internal maupun eksternal keraton. Penelitian ini mengkaji permasalahan: pertama, apa implikasi yuridis dengan dikeluarkannya Sabdatama dan Sabdaraja terhadap UU No. 13 Tahun 2012 tentang Keistimewaan DIY? Kedua, apakah Sabdatama dan Sabdaraja dapat dijadikan sebagai acuan dalam merevisi UU Keistimewaan? Metode penelitian yang digunakan yaitu metode yuridis normatif dengan pendekatan historis dan pendekatan perundang-undangan. Hasil penelitian ini menyimpulkan, pertama, substansi dari Sabdatama dan Sabdaraja bertentangan dengan UUK DIY dan tidak termasuk dalam hirarki peraturan perundang-undangan serta bukan merupakan sumber hukum tata negara. Kedua, Sabdatama dan Sabdaraja tidak tepat jika dijadikan dasar untuk merubah UUK DIY.
\end{abstract}

Kata Kunci: Sri Sultan Hamengku Buwono X, UUK DIY, sabdatama, dan sabdaraja 


\section{LEX Renaissance No. 1 VOL. 1 JANUARI 2016: 17 - 36}

\section{Pendahuluan}

Perubahan Undang-Undang Dasar Negara Republik Indonesia 1945 (UUD NRI Tahun 1945) telah banyak membawa perubahan bagi bangsa Indonesia terhadap beberapa hal. Salah satunya adalah bentuk negara kesatuan dengan sistem pemerintahan yang desentralisasi atau yang dikenal dengan otonomi daerah. ${ }^{1}$ Dalam negara kesatuan dengan sistem desentralisasi, kepada daerah-daerah diberikan kesempatan dan kekuasaan untuk mengatur dan mengurus rumah tangganya sendiri yang dinamakan dengan daerah otonom. ${ }^{2}$ Dianutnya sistem desentralisasi ini telah diakui dalam Bab IV Pasal 18 UUD NRI Tahun 1945. Dalam Pasal 18 ayat (2) UUD NRI Tahun 1945 menyatakan bahwa: "Pemerintah daerah provinsi, daerah kabupaten, dan kota mengatur dan mengurus sendiri urusan pemerintahan menurut asas otonomi dan tugas pembantuan". Adanya sistem desentralisasi maka muncullah otonomi bagi suatu pemerintah daerah.

Pemberian hak, wewenang serta kewajiban kepada pemerintah daerah bukan berarti memberikan kebebasan yang sebebas-bebasnya kepada daerah untuk bertindak dalam hal mengurus rumah tangganya sendiri. Perlu dipahami bahwa sistem desentralisasi yang dianut dalam negara Indonesia masih tetap berada dalam bingkai negara kesatuan. Oleh karena itu, pemerintah daerah harus tetap melakukan koordinasi dengan pemerintah pusat begitu juga sebaliknya.

Lebih lanjut bahwa dalam konsep desentralisasi mengenal adanya desentralisasi asimetris. Desentralisasi asimetris ini sebagai bentuk untuk mengakomodir daerah-daerah khusus maupun daerah istimewa yang ada di Indonesia. Di dalam Bab IV Pasal 18B UUD NRI 1945 menyatakan bahwa: "Negara mengakui dan menghormati satuan-satuan pemerintahan daerah yang bersifat khusus atau bersifat istimewa yang diatur dengan undang-undang." Salah satu daerah yang mendapatkan status istimewa adalah Provinsi Yogyakarta. Pemberian status tersebut dilatar belakangi oleh kedudukan hukum yang dimiliki oleh Yogyakarta berdasarkan sejarah dan hak asal-usul. ${ }^{3}$

Berbicara mengenai keistimewaan Yogyakarta, maka sangat erat kaitannya dengan sejarah dari Daerah Istimewa Yogyakarta (DIY). Sejarah DIY telah berjalan cukup panjang, bahkan sejak sebelum Indonesia merdeka. Dimana awal mula sejarahnya yaitu dari kerajaan

${ }^{1}$ Ni'matul Huda, Desentralisasi Asimetris dalam NKRI: Kajian terhadap Daerah Istimewa, Daerah Khusus, dan Otonomi Khusus, Nusa Media, Bandung, 2014, hlm. 4.

${ }^{2}$ Ibid.

${ }^{3}$ Soejamto, Daerah Istimewa Dalam Negara Kesatuan Republik Indonesia, dalam Suryo Sakti Hadiwijoyo, Menggugat Keistimewaan Yogyakarta: Tarik Ulur Kepentingan, Konflik Elit, dan Isu Perpecahan, Pinus Book Publisher, Yogyakarta, 2009, hlm. 55. 
Mataram yang terbagi dua berdasarkan Perjanjian Giyanti. Sebelum Indonesia merdeka, Yogyakarta merupakan daerah yang mempunyai pemerintahan sendiri atau disebut dengan Daerah Swapraja, yaitu Kasultanan Ngayogyakarta Hadiningrat dan Kadipaten Pakualaman. Setelah proklamasi kemerdekaan RI, Sri Sultan Hamengku Buwono IX dan Sri Pakualaman VIII menyatakan kepada Presiden RI bahwa Kasulatanan Yogyakarta dan Daerah Pakualaman menjadi bagian wilayah sebagai Negara RI. Sri Sultan Hamengku Buwono IX dan Sri Pakualaman VIII sebagai Kepala Daerah dan Wakil Kepala Daerah bertanggung jawab langsung kepada Presiden RI. ${ }^{4}$

Sebagai bentuk tindak lanjut dari Pasal 18B ayat (1) UUD NRI Tahun 1945, maka dibentuklah UU No. 13 Tahun 2012 tentang Keistimewaan DIY (UUK DIY). Dalam UUK DIY dijelaskan bahwasanya yang dimaksud dengan "keistimewaan" adalah keistimewaan kedudukan hukum yang dimiliki oleh DIY berdasarkan sejarah dan hak asal-usul menurut UUD NRI 1945 untuk mengatur dan mengurus kewenangan istimewa. Kewenangan dalam urusan keistimewaan yang dimaksud salah satunya adalah berkaitan dengan tata cara pengisian jabatan, kedudukan, tugas dan wewenang Gubernur dan Wakil Gubernur. ${ }^{5}$

Akhir-akhir ini mencuat berita tentang dikeluarkannya Sabdatama dan Sabdaraja oleh Sri Sultan Hamengku Buwono X yang saat ini sedang menjabat sebagai Gubernur DIY. ${ }^{6}$ Sabdatama dan Sabdaraja merupakan pernyataan raja atas sebuah kebijakan yang harus disampaikan kepada rakyat. Namun, memang ada perbedaannya, yakni Sabdatama ditujukan untuk internal dan eksternal keraton, sedangkan Sabdaraja ditujukan untuk internal keraton saja. ${ }^{7}$

Pada intinya dalam Sabdatama yang disampaikan oleh Sultan adalah melarang pihak luar, termasuk pejabat pemerintahan untuk ikut mencampuri urusan penentuan tahta yakni berkaitan dengan pengisian jabatan Gubernur dan Wakil Gubernur. Selain itu, Sultan juga menginginkan bahwasannya Sabdatama menjadi dasar utama jika diperlukan revisi Undang-Undang Keistimewaan. ${ }^{8}$ Sedangkan inti dari Sabdaraja adalah berkaitan dengan mengakhiri perjanjian Giyanti dan berkaitan dengan pergantian gelar dari "Buwono" menjadi "Bawono", "Sedasa" menjadi "Sepuluh" dan menghilangkan kalimat

\footnotetext{
${ }^{4}$ http://web.jogjaprov.go.id/pemerintahan/situs-tautan/view/ diakses pada 3 Juni 2015.

5Lihat Ketentuan Undang-Undang Nomor 13 Tahun 2012 tentang Keistimewaan Daerah Istimewa Yogyakarta.

${ }^{6}$ http://www.kemendagri.go.id/news/2015/03/06/sultan-hb-x-keluarkan-sabdatama diakses pada 120 Desember 2015.

${ }^{7}$ Hasil wawancara peneliti dengan Gusti Bendoro Pangeran Haryo Yudhaningrat sebagai adik dari Sultan Hamengku Buwono X di Kantor Gubernur Provinsi DIY pada 14 Januari 2016.

${ }^{8} \mathrm{http}: / /$ krjogja.com/read/251505/inilah-sabdatama-sultan-pada-10-mei-2012.kr diakses pada 20 Desember 2015.
} 


\section{LX Renaissance No. 1 VOL. 1 JANUARI 2016: 17 - 36}

"Khalifatullah."9 Dikeluarkannya Sabdatama dan Sabdaraja menimbulkan pro dan kontra di masyarakat luas khususnya DIY, karena yang diubah adalah hal substantif misalnya menghilangkan kalimat "Khalifatullah" dari gelar kebangsawanan Sri Sultan sebagai raja Mataram yang lekat dengan Islam.

Hal yang sangat menarik untuk dibahas adalah apakah bentuk "sabda" yang disampaikan oleh Sri Sultan (sebagaimana isi dari Sabdatama dan Sabdaraja) ini dapat dijadikan sebagai acuan dalam merevisi UU Keistimewaan.

\section{Rumusan Masalah}

Berdasarkan uraian di atas, dirumuskan permasalahan sebagai berikut: pertama, apa implikasi yuridis dengan dikeluarkannya Sabdatama dan Sabdaraja terhadap UU Keistimewaan DIY?. Kedua, apakah Sabdatama dan Sabdaraja dapat dijadikan sebagai acuan dalam merevisi UU Keistimewaan?

\section{Tujuan Penelitian}

Adapun penelitian ini bertujuan untuk mengetahui: pertama, implikasi yuridis dengan dikeluarkannya Sabdatama dan Sabdaraja terhadap UU Keistimewaan DIY. Kedua, apakah Sabdatama dan Sabdaraja dapat dijadikan sebagai acuan dalam merevisi UU Keistimewaan DIY.

\section{Metode Penelitian}

Jenis penelitian ini adalah penelitian hukum normatif, karena peneliti melakukan penelitian dengan studi literatur dan peraturan perundang-undangan yang berhubungan dengan objek penelitian guna mencari jawaban atas masalah yang hendak diteliti. Sumber data yang digunakan dalam penelitian ini adalah bahan-bahan hukum yang terdiri dari bahan hukum primer, bahan hukum sekunder, dan bahan hukum tersier. Penelitian ini menggunakan teknik pengumpulan bahan hukum melalui metode penelitian bahan pustaka (library research) yang terdiri dari buku-buku, jurnal, karya ilmiah, media massa, dan internet serta referensi lain yang relevan dan wawancara.

\footnotetext{
9http://news.liputan6.com/read/2228868/ini-isi-sabda-raja-dan-dawuh-raja?p=1 diakses pada 20 Desember 2015.
} 


\section{Hasil Penelitian dan Pembahasan}

\section{Pengisian Jabatan Gubernur dan Wakil Gubernur di DIY menurut UUK DIY}

Salah satu unsur keistimewaan yang dimiliki oleh DIY adalah berkaitan dengan pengisian jabatan Gubernur dan Wakil Gubernur. Setelah melewati berbagai dinamika pro dan kontra yang terjadi, maka masyarakat Yogyakarta kini dapat merasakan buah hasil kerja keras dari pemerintah Yogyakarta yang pada akhirnya disetujui oleh pemerintah pusat. Hal tersebut yakni berkaitan dengan disahkannya Undang-Undang Nomor 13 Tahun 2012 tentang Keistimewaan Daerah Istimewa Yogyakarta (UUK DIY). Dengan disahkannya UUK DIY tersebut, tentu berbagai hal telah diperjelas dalam UUK DIY terkait hal-hal apa saja yang dapat dikategorikan sebagai daerah istimewa termasuk di dalamnya adalah berkaitan dengan pengisian jabatan Gubernur dan Wakil Gubernur.

Pengisian jabatan Gubernur dan Wakil Gubernur di Provinsi DIY menjadi suatu kewenangan dalam urusan keistimewaan DIY yang berbeda dengan daerah-daerah lainnya yang menyandang status otonomi daerah. Pengisian jabatan Gubernur dan Wakil Gubernur ini sebagaimana yang ditegaskan dalam Pasal 7 ayat (2) UUK DIY adalah berkaitan dengan tata cara pengisian jabatan, kedudukan, tugas, dan wewenang Gubernur dan Wakil Gubernur. Tidak hanya diatur dalam UUK DIY saja, akan tetapi terkait dengan mekanisme atau tata cara pengisian jabatan, kedudukan, tugas, dan wewenang Gubernur dan Wakil Gubernur diatur dalam Peraturan Daerah Istimewa Daerah Istimewa Yogyakarta Nomor 1 Tahun 2013 tentang Kewenangan dalam Urusan Keistimewaan Daerah Istimewa Yogyakarta.

Dalam kaitannya dengan negara Indonesia, konsep ini hanya diterapkan di DIY dan berbeda dengan daerah yang menyandang status otonomi lainnya sebagai konsekuensi dari dimilikinya konsep keistimewaan tersebut. Dalam hal penyelenggaraan kewenangan dalam urusan Keistimewaan sebagaimana dimaksud dalam Pasal 7 ayat (2) Undang-Undang Nomor 13 Tahun 2012 dilaksanakan berdasarkan pada nilai-nilai kearifan lokal dan keberpihakan kepada rakyat.

Penetapan Sri Sultan Hamengku Buwono sebagai Gubernur dan Sri Paku Alam sebagai Wakil Gubernur Provinsi DIY tidak bertentangan dengan prinsip-prinsip demokrasi menurut UUD 1945, karena dalam Pembukaan UUD 1945 para penyusun UUD 1945 sepakat untuk mengadaptasikan bentuk dan model demokrasi yang sesuai dengan budaya dan corak masyarakat Indonesia yakni demokrasi permusyawaratan berdasar kekeluargaan termasuk mengenai mekanisme yang ingin dipraktikkan, sepanjang mekanisme tersebut 


\section{IEX Renaissance No. 1 VOL. 1 JANUARI 2016: 17 - 36}

dipandang demokratis, dalam arti tidak bertentangan dengan gagasan demokrasi permusyawaratan serta tidak mengabaikan hakikat keistimewaan DIY. ${ }^{10}$

Terkait dengan mekanisme pengisian jabatan Gubernur dan Wakil Gubernur, pada dasarnya ada 4 (empat) tahapan yang wajib untuk dilalui oleh calon Gubernur dan Wakil Gubernur sebelum sampai pada tahapan penetapan. Tahap pertama, yakni berkaitan dengan persyaratan yang wajib dipenuhi oleh calon Gubernur dan Wakil Gubernur sebagaimana yang tertuang dalam Pasal 18 ayat (1) UUK DIY. Tahapan kedua, yakni berkaitan dengan tata cara pengajuan calon. Setelah persyaratan telah terpenuhi, maka tahap selanjutnya yang harus dilalui untuk calon Gubernur dan calon Wakil Gubernur adalah mekanisme atau tata cara pengajuan calon yang tertuang dalam Pasal 19 UUK DIY.

Selanjutnya, tahapan ketiga, yakni berkaitan dengan verifikasi sebagaimana yang tertuang dalam Pasal 21, Pasal 22, dan Pasal 23 UUK DIY. Tahapan yang terakhir adalah tahapan keempat, yakni berkaitan dengan penetapan sebagaimana tertuang dalam Pasal 24, Pasal 25, dan Pasal 26 UUK DIY. ${ }^{11}$ Setelah penetapan tersebut, kemudian DPRD DIY mengusulkan kepada Presiden melalui Menteri untuk mendapatkan pengesahan penetapan Sultan Hamengku Buwono yang bertakhta sebagai Gubernur dan Adipati Paku Alam yang bertahta sebagai Wakil Gubernur. Presiden mengesahkan penetapan Gubernur dan Wakil Gubernur berdasalkan usulan menteri tersebut. ${ }^{12}$

Dari beberapa ketentuan terkait dengan mekanisme dalam pengisian jabatan Gubernur dan Wakil Gubernur DIY, maka terlihat bahwa mekanisme pengisian jabatan Gubernur dan Wakil Gubernur DIY berbeda dengan daerah-daerah lainnya sebagaimana yang diatur dalam Pasal 7 Undang-Undang Nomor 8 Tahun 2015 tentang Perubahan atas Undang-Undang Nomor 1 Tahun 2015 tentang Penetapan Peraturan Pemerintah Pengganti Undang-Undang Nomor 1 Tahun 2014 tentang Pemilihan Gubernur, Bupati, dan Walikota menjadi Undang-Undang (UU Pemilukada). Dengan demikian, UUK DIY merupakan lex specialis derogate legi generali ${ }^{13}$ dari UU Pemilukada dan Undang-Undang Nomor 23 Tahun 2014 tentang Pemerintahan Daerah. Sehingga UUK DIY mengesampingkan kedua UU tersebut. Hal ini menunjukkan keistimewaan dari DIY.

${ }^{10}$ Jazim Hamidi \& Mustafa Lutfi, Dekonstruksi Hukum Pengawasan Pemerintahan Daerah (The Turning Point of Local Autonomy), UB Press, Malang, 2011, hlm. ix.

${ }^{11}$ Lihat ketentuan Pasal 24 Undang-Undang Nomor 13 Tahun 2012 tentang Keistimewaan Daerah Istimewa Yogyakarta.

${ }^{12}$ Lihat ketentuan Pasal 24 Undang-Undang Nomor 13 Tahun 2012 tentang Keistimewaan Daerah Istimewa Yogyakarta.

${ }_{13}$ Penafsiran hukum yang menyatakan bahwa hukum yang bersifat khusus (lex specialis) mengesampingkan hukum yang bersifat umum (lex generalis). 
Substansi yang mengalami perbedaan paling signifikan adalah, pertama, bahwa yang menduduki posisi Gubernur dan Wakil Gubernur adalah yang bertahta sebagai Sri Sultan dan Adipati Paku Alam. Kedua, dengan persyaratan yang menyatakan bahwa Gubernur dan Wakil Gubernur harus menyerahkan daftar riwayat hidup yang memuat, antara lain riwayat pendidikan, pekerjaan, saudara kandung, istri, dan anak, maka terlihat bahwa hanya laki-laki saja yang dapat menduduki posisi Gubernur dan Wakil Gubernur. Ketiga, pengisian jabatan Gubernur dan Wakil Gubernur ditempuh dengan mekanisme penetapan bukan pemilihan. Sehingga, masyarakat Yogyakarta tidak ikut andil dalam menetapkan Gubernur dan Wakil Gubernur.

Melalui mekanisme penetapan yang demikian, pada dasarnya tidak berarti meninggalkan asas demokrasi. Hal ini dikarenakan makna "demokratis" 14 tidak hanya dimaknai secara sempit sebagaimana pemilihan langsung yang melibatkan seluruh masyarakat Indonesia, melainkan demokrasi yang dimaksud adalah lebih dinamis, artinya sesuai dengan kebutuhan yang kemudian dilegitimasikan ke dalam aturannya atau dalam hal ini diatur lebih spesifik dalam undang-undang. Dengan tidak terbatasnya makna "demokratis" tersebut berarti dalam praktiknya dapat mengakomodir segala bentuk kebutuhan yang ada dengan cara menggunakan mekanisme lain di luar pemilihan kepala daerah secara langsung oleh rakyat. Karena sejatinya, konstitusi sebuah negara diciptakan harus mampu menjawab segala kebutuhan yang ada atau yang dikenal dengan living constitution.

\section{Implikasi Yuridis Sabdatama dan Sabdaraja terhadap UU Keistimewaan DIY}

Problematika terkait dengan status keistimewaan yang disandang oleh DIY hingga saat ini masih belum tuntas. Banyak hal yang diperdebatkan terkait dengan aspek-aspek yang dikategorikan sebagai suatu hal yang istimewa di DIY salah satunya adalah terkait dengan tata cara pengisian jabatan, kedudukan, tugas, dan wewenang Gubernur dan Wakil Gubernur.

Pada Maret 2015, muncul pemberitaan baik melalui media cetak maupun media elektronik bahwa Sultan Hamengku Buwono X mengeluarkan Sabdatama yang kedua pada

\footnotetext{
14Putusan MK Nomor 072-073/PUU-11/2004 pengujian terhadap tafsir Pasal 18 ayat (4) UUD NRI Tahun 1945 yang mengatur bahwa pemilihan Gubernur, Bupati, dan Walikota dipilih secara demokratis. Melalui putusan MK tersebut, MK menyatakan bahwa makna dari "demokratis" itu adalah dapat dilaksanakan melalui mekanisme pemilihan langsung dan tidak langsung. Makna demokratis merupakan open legal policy (kebijakan terbuka) bagi pembentuk UU. Kalau UU Keistimewaan yang dibuat oleh pembentuk UU itu ditentukan bahwa pemilihan Gubernur dan Wakil Gubernur dilakukan dengan cara penetapan, maka makna demokratis bagi masyarakat Yogyakarta melalui mekanisme penetapan tersebut.
} 


\section{Lx Renaissance No. 1 VOL. 1 JANUARI 2016: 17 - 36}

6 Maret 2015 yang sebelumnya telah dikeluarkan pada 10 Mei 2012. Kemudian, pada 1 Mei dan 5 Mei 2015 Sultan Hamengku Buwono X kembali mengeluarkan sabdanya namun istilahnya berbeda dengan Sabdatama yakni Sabdaraja dan Dhawuhraja. Baik Sabdatama, Sabdaraja, maupun Dhawuhraja pada intinya merupakan perkataan raja baik yang ditujukan ke internal keraton maupun pihak yang berada di eksternal keraton.

Isi dari Sabdatama pertama yang dikeluarkan pada tanggal 10 Mei 2012 pada intinya berkaitan dengan diundangkannya UUK DIY yang menyatakan bahwa: ${ }^{15}$

\section{Sebagai Raja Mataram Sultan menyatakan:}

Bahwa Keraton Yogyakarta dan Kadipaten Pakualaman adalah dwi tunggal.

Mataram merupakan Negeri Merdeka dan memiliki tata hukum dan tata negara sendiri. Seperti yang dikhendaki dan diizinkan, Mataram melingkungi Nusantara, menegakkan negara, tetapi menggunakan aturan dan tata negara sendiri.

Sedang Sultan dan Paku Alam yang jumeneng ditetapkan sebagai Gubernur dan Wakil Gubernur.

Yogyakarta, Tanggal 10 Mei 2012

\section{Hamengku Buwono X}

Sedangkan Sabdatama kedua yang dikeluarkan pada tanggal 6 Maret 2015 menyatakan bahwa: ${ }^{16}$

Mengertilah, aku juga mematuhi aturan, tata krama, dan janji terhadap Tuhan yang

Mahakuasa, serta menghormati para leluhur. Oleh karena itu, aku memberi perintah:

1. Tidak seorang pun boleh melebihi kewenangan keraton (Raja).

2. Tidak seorang pun bisa memutuskan atau membicarakan persoalan Mataram. Terlebih berkaitan dengan Raja, termasuk tatanan dan aturan pemerintahannya. Yang bisa memutuskan hanya Raja.

3. Barang siapa yang sudah diberikan jabatan harus mengikuti perintah Raja yang memberikan jabatan.

4. Siapa saja yang merasa bagian dari alam dan mau menjadi satu dengan alam, dialah yang layak diberi dan diperbolehkan melaksanakan perintah dan bisa dipercaya. Ucapannya harus bisa dipercaya, tahu siapa jati dirinya, menghayati asal-usulnya. Bagian ini sudah ada yang mengatur. Bila ada pergantian, tidak boleh diganggu.

5. Siapa saja yang menjadi keturunan keraton, laki atau perempuan, belum tentu dianugerahi kewenangan kerajaan. Yang diberi wewenang sudah ditunjuk. Jadi, tidak ada yang diperbolehkan membahas atau membicarakan soal takhta Mataram, terlebih-lebih para pejabat istana, khawatir terjadi kekeliruan.

6. Sabdatama ini dimunculkan sebagai rujukan untuk membahas apa saja, juga menjadi tata cara keraton dan negara, dan berlaku seperti undang-undang.

7. Sabdatama yang lalu terkait perda istimewa dan dana istimewa.

\footnotetext{
${ }^{15} \mathrm{http}: / /$ krjogja.com/read/251505/inilah-sabdatama-sultan-pada-10-mei-2012.kr diakses pada 20 Desember 2015.

${ }^{16}$ http://www.kemendagri.go.id/news/2015/03/06/sultan-hb-x-keluarkan-sabdatama diakses pada 20 Desember 2015.
} 
8. Jika membutuhkan untuk memperbaiki Undang-Undang Keistimewaan, dasarnya sabdatama.

Itu perintah semua yang perlu dimengerti dan dipegang.

Kemudian isi dari Sabdaraja yang dikeluarkan pada tanggal 1 Mei 2015, menyatakan bahwa: ${ }^{17}$

Gusti Allah Yang Maha Agung dan Pencipta, mengertilah kalian semua anak-anakku, adik-adikku, keluargaku dan abdiku. Menerima pesan perintah Gusti Allah dan ayahku serta leluhurku Mataram. Mulai saat ini saya saya menerima perintah kebahagiaan perintah Gusti Allah bahwa namaku menjadi Ngarsa Dalem Sampeyan Dalem Ingkang Sinuwun Sri Sultan Hamengku Bawono Ingkang Jumeneng Kasepuluh Suryaning Mataram Senopati Ing Ngalaga Langgeng Ing Bawono Langgeng Langgeng Ing Tata Panatagama. Sabdaraja ini perlu dimengerti, dipatuhi dan dilaksanakan. Demikian sabdaku.

Selanjutnya isi dari Dhawuhraja yang dikeluarkan pada tanggal 5 Mei 2015, menyatakan bahwa: ${ }^{18}$

Saudara semua, saksikanlah saya Ngarsa Dalem Sampeyan Dalem Ingkang Sinuwun Sri Sultan Hamengku Bawono Ingkang Jumeneng Kasepuluh Suryaning Mataram Senopati Ing Ngalaga Langgeng Ing Bawono Langgeng Langgeng Ing Tata Panatagama diperintahkan untuk menetapkan putriku Gusti Kanjeng Ratu Pambayun katetepake Gusti Kanjeng Ratu Mangkubumi Hamemayu Hayuning Bawono Langgeng Ing Mataram. Mengetahuilah, begitulah perintah saya.

Dari isi Sabdatama, Sabdaraja, maupun Dhawuhraja di atas, maka ada beberapa poin penting yang dapat dikaji terkait dengan poin perubahannya, yakni: 1. Poin Sabdatama: Poin nomor 6 dan 8. Permasalahan Sabdatama bukan soal materinya tetapi lebih mempersoalkan kekuatan hukum Sabdatama dalam negara. 2. Poin Sabdaraja: Penggantian nama sultan Ngarsa Dalem Sampeyan Dalem Ingkung Sinuwun Kanjeng Sultan Hamengku Senopati Ing Ngalaga Ngabdurrahman Sayidin Panatagama Khalifaatullah atau yang disebut Sri Sultan Hamengku Buwono. Permasalahannya terletak pada materinya karena mengubah apa yang ditentukan oleh UUK DIY. 3. Poin Dhawuhraja: yang menjadi poin permasalahannya adalah nama Sultan dan penetapan anaknya sebagai penerus. Hal ini jelas telah melawan UUK DIY.

Ketiga poin di atas erat kaitannya dengan isi atau materi muatan yang ada di dalam UUK DIY. Hal tersebutlah yang menyebabkan timbulnya pro dan kontra yang terjadi di

\footnotetext{
${ }^{17}$ http://news.liputan6.com/read/2228868/ini-isi-sabda-raja-dan-dawuh-raja?p=1 diakses pada 20 Desember 2015.

${ }^{18}$ http://news.liputan6.com/read/2228868/ini-isi-sabda-raja-dan-dawuh-raja?p=1 diakses pada 20 Desember 2015.
} 


\section{IEX Renaissance No. 1 VOL. 1 JANUARI 2016: 17 - 36}

kalangan masyarakat Yogyakarta. ${ }^{19}$ Bahkan dari keluarga keraton pun yakni 15 (lima belas) adik Raja Keraton Kasultanan Ngayogyakarta Hadiningrat Sri Sultan Hamengku Buwono $\mathrm{X}$ membuat surat terbuka yang disampaikan kepada Presiden Republik Indonesia sebagai bentuk ketidaksetujuan dari mereka terhadap pernyataan Sultan Hamengku Buwono X tersebut. $^{20}$

Pro dan kontra yang terjadi juga dapat dilihat dari pemberitaan baik yang ada di media massa, media cetak, bahkan bentuk penolakan yang dilakukan oleh masyarakat dituangkan di spanduk-spanduk yang dipasang di pinggir-pinggir jalan Kota Yogyakarta. ${ }^{21}$

Menurut analisis peneliti, ada beberapa isi dari Sabdatama, Sabdaraja, dan Dhawuhraja dapat dikatakan tidak tepat bahkan bertentangan dengan UUK DIY. Sehingga hal tersebut menimbulkan polemik di masyarakat. Pertama, dari isi Sabdatama yang menyatakan bahwa: "Jika membutuhkan untuk memperbaiki Undang-Undang Keistimewaan, dasarnya Sabdatama dan Sabdatama ini dimunculkan sebagai rujukan untuk membahas apa saja, juga menjadi tata cara keraton dan negara, dan berlaku seperti undangundang”. Pertanyaannya adalah apakah Sabdatama dapat dijadikan dasar untuk merubah UUK DIY?

Kedua, perubahan nama Ngarsa Dalem Sampeyan Dalem Ingkung Sinuwun Kanjeng Sultan Hamengku Senopati Ing Ngalaga Ngabdurrahman Sayidin Panatagama Khalifatullah atau yang disebut Sri Sultan Hamengku Buwono. Ada beberapa poin perubahan nama tersebut melalui Sabdaraja dan Dhawuhraja. ${ }^{22}$ 1. Kata Kanjeng dihilangkan dan diganti dengan kata Sri. 2. Kata Buwono dihilangkan dan diganti dengan kata Bawono. 3. Kata Ingkang Jumeneng Kaping Sedasa dihilangkan dan diganti dengan kata Ingkang Jumeneng Kaping Kasepuluh. 4. Ada penambahan kata Suryaning Mataram. 5. Kata Khalifatullah dihilangkan dan diganti dengan kata Langgeng Ing Panatagama.

Ketiga, perubahan nama Sultan dan penetapan anaknya sebagai penerus tahta keraton. isu politik yang muncul adalah dengan adanya perubahan nama tersebut, Sri Sultan Hamengku Buwono ingin mempersiapkan penerus tahta atau posisinya baik di lingkungan keraton maupun lingkungan pemerintahan kepada anak perempuannya. Hal ini dikarenakan,

\footnotetext{
${ }^{19} \mathrm{http}: / /$ nasional.tempo.co/read/news/2015/05/07/058664258/hari-ini-adik-sultan-penolak-sabda-rajatunggu-masukan diakses pada tanggal 26 Desember 2015.

${ }^{20}$ Hasil wawancara peneliti dengan Gusti Bendoro Pangeran Haryo Yudhaningrat sebagai adik dari Sultan Hamengku Buwono X di Kantor Gubernur Provinsi DIY pada tanggal 14 Januari 2016.

${ }^{21} \mathrm{http}: / /$ sorotjogja.com/penolakan-bertebaran-sejumlah/ diakses pada 26 Desember 2015.

22“Implikasi Sabdaraja dan Dhawuhraja terhadap UU No. 13 Tahun 2012 Tentang Keistimewaan DIY”, disampaikan oleh Ni'matul Huda dalam acara Pengajian dan Buka Bersama dengan Tema "Membaca Masa Depan Keistimewaan DIY di Tengah-tengah Arus Demokratisasi" yang diselenggarakan oleh LBH KAHMI DIY, Yogyakarta, Selasa, 27 Juni 2015.
} 
Sri Sultan tidak mempunyai keturunan laki-laki maka dengan merubah nama anggapannya dapat mengakomodir keinginan dari Gubernur DIY tersebut. Hal ini jelas telah melawan UUK DIY.

Secara yuridis, tentu perubahan nama tersebut membawa implikasi tersendiri bagi UUK DIY. Implikasi tersebut telah membawa perubahan terhadap 10 Pasal yang ada dalam UUK DIY. Namun, perlu dipertanyakan kembali apakah melalui Sabdaraja dan Dhawuhraja tersebut mampu untuk merubah UUK DIY?

Selain itu, keinginan Sultan Hamengku Buwono X untuk menurunkan tahtanya kepada anak perempuannya melalui Sabdaraja dan Dhawuhraja ini tidak sesuai dengan UUK DIY. Hal ini dikarenakan, di dalam UUK DIY tepatnya di dalam Pasal 18 ayat (1) huruf $m$ yang berkaitan dengan persyaratan untuk menjadi Calon Gubernur dan Calon Wakil Gubernur wajib untuk menyerahkan daftar riwayat hidup yang memuat, antara lain riwayat pendidikan, pekerjaan, saudara kandung, istri, dan anak. Kata "istri” dari Pasal 18 ayat (1) huruf $\mathrm{m}$ tersebut dapat dimaknai bahwa yang dapat menjadi Calon Gubernur dan Calon Wakil Gubernur hanyalah seorang pria atau laki-laki. Oleh karena itu, dengan isi Sabdaraja dan Dhawuhraja yang kontradiksi dengan UUK DIY maka terlihat sebagai bentuk inkonsistensi Sultan terhadap Sabdatama pertama yakni keinginan Sultan untuk membentuk UUK DIY.

Substansi yang terkait dengan Sabdatama, Sabdaraja, dan Dhawuhraja setidaknya bisa dipersoalkan melalui tinjauan peraturan perundang-undangan dan tinjauan sumber hukum tata negara. Hasil tinjauan dari peneliti adalah sebagai berikut :

\section{Ditinjau dari Perspektif Hierarki Peraturan Perundang-undangan}

Di satu sisi, isi Sabdatama, Sabdaraja, dan Dhawuhraja, dianggap telah bertentangan dengan teori peraturan perundang-undangan. Hal ini dikarenakan hierarki peraturan perundang-undangan terdiri dari: ${ }^{23}$ 1. UUD NRI Tahun 1945; 2. Ketetapan MPR; 3. UU/Peraturan Pemerintah Pengganti UU; 4. Peraturan Pemerintah; 5. Peraturan Presiden; 6. Peraturan Daerah Provinsi; dan 7. Peraturan Daerah Kabupaten/Kota.

Dalam kaitannya dengan norma hukum, Hans Kelsen mengemukakan teorinya mengenai jenjang norma hukum (stufenttheorie), yang menyatakan bahwa norma-norma hukum itu berjenjang-jenjang dan berlapis-lapis dalam suatu hierarki tata susunan, di mana suatu norma yang lebih rendah berlaku, bersumber, dan berdasar pada norma yang lebih

${ }^{23}$ Lihat ketentuan Pasal 7 Undang-Undang Nomor 12 Tahun 2011 tentang Pembentukan Peraturan Perundang-Undangan (UU P3). 


\section{IEX Renaissance No. 1 VOL. 1 JANUARI 2016: 17 - 36}

tinggi, norma yang lebih tinggi berlaku, bersumber dan berdasar pada norma yang lebih tinggi lagi, demikian seterusnya sampai pada suatu norma yang tidak dapat ditelusuri lebih lanjut dan bersifat hipotesis dan fiktif, yaitu norma dasar (Grundnorm). ${ }^{24}$ Norma dasar yang merupakan norma tertinggi dalam sistem norma perundang-undangan tersebut tidak lagi dibentuk oleh suatu norma yang lebih tinggi lagi. ${ }^{25}$

Teori Hans Kelsen ini kemudian dikembangkan lebih lanjut oleh salah satu muridnya, yakni Hans Nawiasky. Di dalam bukunya berjudul Allgemeine Rechtslehre, Hans Nawiasky menyatakan bahwa suatu norma hukum di negara maupun tidak saja selalu berlapas dan berjenjang, di mana norma yang dibawah dan mengacu pada norma diatasnya, sedangkan norma yang lebih tinggi berlaku dan bersumber pada norma yang lebih tinggi lagi, tetapi juga norma hukum itu berkelompok-kelompok. ${ }^{26}$ Kelompok norma hukum itu, ialah (i) norma hukum fundamental negara (staatsfundamentalnorm); (ii)aturan dasar atau aturan pokok negara (staatsgrundgesetz); (iii) undang-undang formal (formellgesetz); dan (iv) aturan pelaksana dan aturan otonom (verordnung und autonomesatzung). ${ }^{27}$ Dalam hal tata susunan atau hierarki sistem norma, norma yang lebih tinggi (norma dasar) itu menjadi tempat bergantungnya norma-norma dibawahnya sehingga apabila norma dasar itu berubah, menjadi rusaklah sistem norma yang berada dibawahnya. ${ }^{28}$

Oleh karena itu, untuk melihat apakah dapat Sabdatama, Sabdaraja, dan Dhawuhraja yang dikeluarkan oleh Sultan Hamengku Buwono X dapat menjadi dasar perubahan UUK DIY maka dapat dilihat dari hierarki peraturan perundang-undangan yang ada di Indonesia. Ketika di dalam hierarki tersebut tidak memuat adanya Sabdatama, Sabdaraja, dan Dhawuhraja dalam hierarki peraturan perundang-undangan maka hal demikian menjadi persoalan baru karena Sabdatama, Sabdaraja, dan Dhawuhraja tidak termasuk dalam salah satu bentuk peraturan yang dimuat dalam hierarki peraturan perundang-undangan.

Kemudian di dalam Pasal 9 ayat (1) UU tentang Pembentukan Peraturan PerundangUndangan (P3) menyatakan bahwa: "Dalam hal suatu Undang-Undang diduga bertentangan dengan Undang-Undang Dasar Negara Republik Indonesia Tahun 1945, pengujiannya dilakukan oleh Mahkamah Konstitusi”. Pernyataan dari Pasal 9 ayat (1) UU P3 tersebut secara tersirat menunjukkan bahwa, suatu Undang-Undang dapat dilakukan perubahan karena telah bertentangan atau tidak sesuai dengan perkembangan hanya dilihat berdasarkan

\footnotetext{
${ }^{24}$ Hans Kelsen "Allgemeine Theorie der Normen, Wien: Manzsche Verlag \& Universitatsbuchhandlung” dalam Soimin, Pembentukan Peraturan Perundang-Undangan Negara di Indonesia”, UII Press, Yogyakarta, 2010, hlm. 39. ${ }^{25}$ Ibid.

${ }^{26}$ Sumali "Reduksi Kekuasaan Eksekutif: Di Bidang Peraturan Pengganti Undang-Undang (PERPU)" dalam Soimin, Pembentukan Peraturan Perundang-Undangan...,Op. Cit., hlm. 40.

${ }^{27}$ Ibid.

28Soimin, Pembentukan Peraturan Perundang-Undangan...,Op. Cit., hlm. 40.
} 
pada UUD NRI Tahun 1945. Dari pernyataan yang demikian, maka akan timbul satu pertanyaan yang mendasar yakni bagaimana dengan isi Sabdatama, Sabdaraja, dan Dhawuhraja yang dikeluarkan oleh Sultan Hamengku Buwono X? Apakah Sabdatama tersebut memiliki kekuatan hukum yang setara dengan UUD NRI Tahun 1945 sehingga dapat dijadikan dasar untuk melakukan perubahan UUK DIY?

Untuk menjawab pertanyaan tersebut, maka terlebih dahulu perlu dipahami secara jelas makna dari Sabdatama. Secara makna Sabdatama adalah pernyataan raja atas sebuah kebijakan yang harus disampaikan kepada rakyat. ${ }^{29}$ Sabdatama yang dimaksud dalam tulisan ini ditujukan kepada kalangan internal dan eksternal keraton. Sedangkan, Sabdaraja dan Dhawuhraja adalah perkataan raja yang disampaikan kepada rakyatnya. Sabdaraja yang dimaksud dalam tulisan ini ditujukan kepada kalangan internal keraton. ${ }^{30}$ Antara definisi Sabdatama dan Sabdaraja sebenarnya sama saja, akan tetapi berbeda secara fonetik atau pengucapannya serta tujuannya. ${ }^{31}$ Secara yuridis, Sabdatama, Sabdaraja, dan Dhawuhraja tidak dikenal di dalam hierarki peraturan perundang-undangan. Ketiga istilah tersebut hanya digunakan di lingkungan keraton saja. Artinya, Sabdatama, Sabdaraja, dan Dhawuhraja hanya memiliki legitimasi dilingkungan keraton, namun tidak memiliki legitimasi di lingkungan pemerintahan.

Ketika, Sultan Hamengku Buwono X menyatakan dalam Sabdanya bahwa ketika ingin melakukan perubahan terhadap UUK DIY didasarkan pada Sabdatama dan merubah nama Sultan yang terdapat dalam UUK DIY melalui Sabdaraja dan Dhawuhrajanya, maka menurut peneliti pernyataan tersebut tidaklah tepat. Karena pada dasarnya, Sabdatama, Sabdaraja, dan Dhawuhraja tidak diakui dimata hukum Indonesia, artinya tidak dapat dijadikan acuan atau dasar untuk melakukan perubahan UUK DIY.

Produk hukum yang berbentuk Undang-Undang merupakan bentuk hukum peraturan yang paling tinggi statusnya di bawah UUD NRI 1945 dan di dalam UU P3 pun sudah secara jelas menguraikan terkait dengan hierarki peraturan perundang-undangan. Sehingga sekali lagi peneliti menegaskan bahwa Sabdatama, Sabdaraja, dan Dhawuhraja tidak termasuk dalam hierarki peraturan perundang-undangan sebagaimana dimaksud dalam UU P3.

Dari hierarki peraturan perundang-undangan sebagaimana yang telah dipaparkan di atas, terlihat bahwa sama sekali tidak mengatur terkait dengan Sabdatama, Sabdaraja, dan

${ }^{29}$ http://brainly.co.id/tugas/1035580 diakses pada 9 Juni 2015

${ }^{30}$ http:/ / kbbi.web.id/ diakses pada 9 Juni 2015

${ }^{31}$ http:/ / bayudardias.staff.ugm.ac.id/2015/05/06/sabdatama-sabdaraja-sultan diakses pada 18 Januari 2016.

hamengkubuwono-x/ 


\section{LEX Renaissance No. 1 VOL. 1 JANUARI 2016: 17 - 36}

Dhawuhraja. Oleh karena itu, maka dapat disimpulkan bahwa Sabdatama, Sabdaraja, dan Dhawuhraja bukanlah suatu peraturan perundang-undangan. Sehingga tidak dapat dijadikan dasar untuk mengajukan perubahan terhadap UUK DIY.

\section{Ditinjau dari Perspektif Sumber Hukum Tata Negara}

Ketiga istilah yaitu Sabdatama, Sabdaraja dan Dhawuhraja dapat dipersoalkan melalui tinjauan sumber hukum tata negara. Dalam sumber HTN terdapat sumber hukum formal dan materiil. Ada beberapa hal yang mendasari mengapa Sabdatama, Sabdaraja dan Dhawuhraja tidak dapat dikatakan sebagai sumber hukum formal dan materiil.

Pada dasarnya hukum tata negara mengenal adanya sumber hukum tata negara. Sumber hukum inilah yang menjadi dasar dalam pembentukan aturan-aturan yang kaitannya dengan ketatanegaraan. Secara teori bahwa ada 2 sumber hukum tata negara, yakni Sumber hukum formal dan materiil. ${ }^{32}$

Salah satu sumber hukum formal adalah hukum adat ketatanegaraan. Hukum adat ketatanegaraan menunjuk kepada suatu bagian dari pada hukum golongan, yaitu hukum bagi orang-orang Indonesia asli yang mengatur mengenai tatanan persekutuan-persekutuan hukum beserta alat-alat kekuasaannya, baik dalam segi yang statis maupun dalam seginya yang dinamis. ${ }^{33}$ Dalam sistem hukum nasional, persoalan-persoalan yang menjadi tugas Hukum Adat Tata Negara dapat ditinjau dari asas-asas gotong royong, fungsi sosial manusia dan milik dalam masyarakat hukum, susunan dari pada masyarakat-masyarakat hukum, soal-soal yang berkenan dengan sifat pemimpin dari kepala-kepala adat dan sistem pengangkatan atau pemilihannya, tugas kepala adat, bentuk pemerintahan dari masyarakat hukum serta suasana dari masyarakat hukum. ${ }^{34}$

Secara teori yang dimaksud dengan adat ketatanegaraan adalah bagian dari hukum adat yaitu hukum tidak tertulis yang bersumber dari adat istiadat dan atau putusan penguasa adat. ${ }^{35}$ Sejak kemerdekaan telah terjadi perubahan-perubahan mengenai bentuk, susunan, dan isi organisasi negara yang diatur dalam bermacam-macam peraturan perundangundangan. ${ }^{36}$ Hukum adat ketatanegaraan semakin berkurang peranannya. Walaupun dalam beberapa hal masih tampak pada penyelenggaraan pemerintahan desa, seperti rembung desa (musyawarah desa), hukum adat tata negara berangsur-angsur diganti oleh hukum

${ }^{32}$ Ni’matul Huda, Hukum Tata Negara Indonesia, PT Rajagrafindo Persada, Jakarta, 2006, hlm. 32.

${ }^{33}$ Moh Koesnoe "Catatan-Catatan Terhadap Hukum Adat Dewasa Ini" dalam Muhammad Athar Hasimin, "Pengaruh Nilai-nilai Tasawuf dalam Tata Negara Adat (Studi Konstitusi Martabat Tujuh Kesultanan Buton)", Fakultas Hukum, UII, 2009, hlm. 43.

${ }^{34}$ Ibid.

${ }^{35}$ Bagir Manan, Konvensi Ketatanegaraan, FH UII Press, Yogyakarta, 2006, hlm. 37.

${ }^{36}$ Ibid. 
perundang-undangan dan konvensi. Contoh dari hukum tata negara adat yang berasal dari zaman dahulu adalah: ketentuan-ketentuan mengenai swapraja (kedudukannya, struktur pemerintahannya, organisasi jabatan-jabatan yang ada didalamnya, dan sebagainya), mengenai-mengenai persekutuan-persekutuan hukum kenegaraan asli lainnya (desa, kuria, gampong, dan sebagainya), dan mengenai peradilan agama. ${ }^{37}$ Apabila Sabdatama, Sabdaraja, dan Dhawuhraja dikatakan sebagai sumber hukum formal adat ketatanegaraan maka tidaklah tepat karena hingga saat ini Sabdatama, Sabdaraja, dan Dhawuhraja belum sepenuhnya diakui baik dari kalangan internal maupun eksternal keraton. ${ }^{38}$

Selain itu, jika dikatakan hukum adat biasapun tidak tepat karena menurut Snouck Hurgronje menyatakan bahwa hukum adat diartikan sebagai kebiasaan-kebiasaan yang merupakan hasil kesepakatan dan dilaksanakan oleh masyarakat karena adanya aturanaturan yang mengandung akibat-akibat hukum. ${ }^{39}$ Kata "kesepakatan" dan "dilaksanakan oleh masyarakat" menunjukkan bahwa Sabdatama, Sabdaraja, dan Dhawuhraja tidak termasuk dalam hukum adat. Karena sekali lagi dikatakan bahwa Sabdatama, Sabdaraja, dan Dhawuhraja bukan hasil kesepakatan tetapi salah satu bentuk ketetentuan sepihak yang dikeluarkan oleh Sultan Hamengku Buwono X dan hingga saat ini belum sepenuhnya dilaksanakan baik dari kalangan internal maupun eksternal keraton.

Adapun yang dimaksud dengan konvensi ketatanegaraan atau kebiasaan ketatanegaraan adalah perbuatan dalam kehidupan ketatanegaraan yang dilakukan berulang kali, sehingga ia diterima dan ditaati dalam praktik penyelenggaraan negara, walaupun ia bukan hukum. ${ }^{40}$ K.C Wheare menyatakan bahwa, konvensi terbentuk dengan 2 (dua) cara, yakni: $^{41}$ 1. Suatu praktik tertentu berjalan untuk jangka waktu yang lama. Mula-mula bersifat persuasif, kemudian diterima sebagai suatu hal yang wajib (kewajiban). 2. Konvensi terjadi melalui kesepakatan diantara rakyat. Mereka sepakat melaksanakan sesuatu dengan cara-cara tertentu, dan sekaligus menetapkan ketentuan mengenai cara-cara pelaksanaannya.

Lebih lanjut lagi bahwa, A.V Dicey mengemukakan konvensi ketatanegaraan adalah bagian dari kaidah ketatanegaraan (konstitusi) yang tumbuh, diikuti, dan ditaati dalam

\footnotetext{
${ }^{37}$ Bagir Manan "Konvensi Ketatanegaraan", Usep Ranawijaja " Hukum Tata Negara Dasar-dasarnya" dalam Ni'matul Huda, Hukum Tata...,Op.Cit., hlm. 34.

${ }^{38}$ Hasil wawancara peneliti dengan Gusti Bendoro Pangeran Haryo Yudhaningrat sebagai adik dari Sultan Hamengku Buwono X di Kantor Gubernur Provinsi DIY pada tanggal 14 Januari 2016.

${ }^{39}$ Otje Salman Soemadiningrat, Rekonseptualisasi Hukum Adat Kontemporer, PT. Alumni, Bandung, 2002, hlm. 109. hlm. 51.

${ }^{40}$ Moh. Kusnardi dan Harmaily Ibrahim, Pengantar Hukum Tata Negara Indonesia, Sinar Bakti, Jakarta, 1988, ${ }^{41}$ K.C Where "Modern Constitutions" dalam Bagir Manan, Konvensi...,Op. Cit., hlm. 61.
} 


\section{Lx Renaissance No. 1 VOL. 1 JANUARI 2016: 17 - 36}

praktik penyelenggaraan negara. ${ }^{42}$ Dari definisi konvensi ketatanegaraan yang dikemukakan oleh 2 (dua) tokoh maka apabila dikatakan Sabdatama, Sabdaraja dan Dhawuhraja sebagai konvensi ketatanegaraan juga tidak tepat. Jika dilihat dari unsurnya "berulang-ulang" kali memang benar bahwa Sabdatama, Sabdaraja, dan Dhawuhraja dikeluarkan oleh Sultan Hamengku Buwono X tidak hanya satu kali saja tetapi lebih dari satu kali. Namun, jika dilihat dari unsur "diterima dan ditaati dalam penyelenggaraan negara" maka tidaklah tepat. Hal ini dikarenakan dengan diterbitkannya Sabdatama, Sabdaraja dan Dhawuhraja banyak menimbulkan polemik-polemik di masyarakat. Bahkan keluarga keraton atau internal keraton sendiri pun banyak yang melakukan pertentangan terhadap sabda-sabda tersebut. Hingga saat ini khusus untuk Sabdatama 2, Sabdaraja 1 dan 2 serta Dhawuhraja yang ada saat ini belum diberlakukan di sistem pemerintahan DIY. Oleh karena itu, dapat ditarik kesimpulan bahwa Sabdtama, Sabdaraja dan Dhawuhraja yang mengatur tentang pemerintahan ini tidak dapat dikategorikan sebagai sumber hukum formal karena dalam perkembangannya Sabdatama, Sabdaraja, dan Dhawuhraja belum sepenuhnya diakui karena subtansinya bertentangan baik dengan UUD NRI 1945 maupun UU Keistimewaan.

Selanjutnya berkaitan dengan sumber hukum materiil adalah bahwa inti dari sumber hukum materiil yakni faktor-faktor yang mempengaruhi pembentukan hukum. Menurut peneliti, jika dikaitkan dengan Sabdatama, Sabdaraja dan Dhawuhraja, maka sejatinya aturan-aturan tersebut sampai saat ini belum memiliki pengaruh terhadap UUK DIY. Sebab kembali lagi dikatakan bahwa Sabdatama, Sabdaraja dan Dhawuhraja belum sepenuhnya diakui oleh masyarakat maupun pemerintahan DIY itu sendiri. Sehingga tidak memiliki pengaruh apapun terhadap UUK DIY dan tidak termasuk sebagai sumber hukum materiil. Dengan demikian, dari analisis peneliti di atas maka Sabdatama, Sabdaraja dan Dhawuhraja tidak termasuk dalam sumber hukum tata negara, baik sumber hukum formil maupun materiil karena belum sepenuhnya diakui dan tidak memberikan implikasi apapun terhadap pembentukan hukum khususnya dalam UUK DIY.

Pertentangan yang dinyatakan oleh 15 Adik Sultan Hamengku Buwono X tidak hanya terkait dengan isi Sabdatama, Sabdaraja, dan Dhawuhraja yang bertentangan dengan UUK DIY, akan tetapi yang terpenting bagi mereka bahwa isi dari Sabdatama, Sabdaraja, dan Dhawuhraja juga bertentangan dengan paugeran (aturan tertinggi keraton yang merupakan peninggalan dari nenek moyang). Terkait dengan paugeran itu sendiri, sebenarnya juga telah dikatakan di dalam Pasal 43 huruf a UUK DIY bahwa "Gubernur selaku Sultan Hamengku Buwono yang bertakhta dan/atau Wakil Gubernur selaku Adipati

\footnotetext{
${ }^{42}$ Ibid., hlm. 60
} 
Paku Alam yang bertakhta berdasarkan undang-undang ini bertugas melakukan penyempurnaan dan penyesuaian peraturan di lingkungan Kasultanan dan Kadipaten”. Istilah "penyesuaian peraturan di lingkungan Kasultanan dan Kadipaten" dimaknai sebagai paugeran. Akan tetapi dengan adanya Sabdatama, Sabdaraja, dan Dhawuhraja tersebut mengindikasikan bahwa Sultan Hamengku Buwono X telah melanggar UUK DIY.

Menurut peneliti, dengan dikeluarkannya Sabdatama, Sabdaraja dan Dhawuhraja oleh Sultan Hamengku Buwono X dalam posisinya sebagai Sultan Keraton Ngayogyakarta bukan sebagai kepala pemerintahan di Yogyakarta. Artinya, di sini sudah seharusnya Sultan Hamengku Buwono X dapat memisahkan posisinya baik sebagai Kepala Pemerintahan atau sebagai Kepala Keraton. Ketika Sultan Hamengku Buwono X benar-benar ingin mengesahkan Sabdaraja dan Dhawuhraja tersebut, maka Sultan Hamengku Buwono wajib mengajukan perubahan terhadap UUK DIY sesuai dengan prosedur yang berlaku dan bersedia menerima berbagai konsekuensi logis ketika UUK DIY mengalami perubahan.

Konteks keistimewaan yang dimiliki oleh DIY bukan berarti DIY memiliki hak yang sebebas-bebasnya untuk melakukan tindakan hukum tertentu. Keistimewaan yang dimiliki oleh DIY haruslah tetap berada dalam bingkai negara kesatuan. Konsep otonomi daerah dan keistimewaan yang dipraktikkan selama ini haruslah tetap berada dalam bingkai NKRI.

Pasal 18B ayat (1) UUD NRI Tahun 1945 telah jelas menyatakan bahwa: "Negara mengakui dan menghormati satuan-satuan pemerintahan daerah yang bersifat khusus atau bersifat istimewa yang diatur dengan Undang-Undang." Ini artinya, status keistimewaan DIY memang diakui di mata konstitusi Indonesia, akan tetapi status keistimewaan tersebut harus memiliki payung hukum yakni Undang-Undang. Sehingga, segala sesuatu yang dilakukan maupun yang diatur di DIY itu haruslah berdasarkan pada UU. Hingga saat ini, UU yang mengaturnya adalah UU Nomor 13 Tahun 2012 tentang Keistimewaan Daerah Istimewa Yogyakarta. Oleh karena itu, kaitannya dengan Sabdatama, Sabdaraja dan Dhawuhraja ini tidak diatur di dalam UUK DIY. Sehingga tidak dapat serta merta ketika Sabdatama, Sadaraja dan Dhawuhraja tersebut dikeluarkan oleh Sultan Hamengku Buwono $\mathrm{X}$ secara otomatis berlaku.

Apabila Sultan Hamengku Buwono $\mathrm{X}$ ingin mengesahkan isi dari Sabdatama, Sabdaraja dan Dhawuhraja tersebut, maka Sultan harus mengajukan perubahan UUK DIY kepada Dewan Perwakilan Rakyat Republik Indonesia (DPR RI). Perubahan suatu peraturan perundang-undangan dilakukan oleh pejabat yang berwenang membentuknya, berdasarkan prosedur yang telah berlaku dan dengan suatu peraturan perundang-undangan yang 


\section{Lx Renaissance No. 1 VOL. 1 JANUARI 2016: 17 - 36}

sejenis. ${ }^{43}$ Pejabat yang dimaksud disini adalah DPR RI. Hal demikian dikarenakan DPR memiliki kewenangan untuk membuat undang-undang maka DPR pula yang memiliki kewenangan untuk melakukan perubahan. Dalam Pasal 20 ayat (1) UUD NRI Tahun 1945 menyatakan, "Dewan Perwakilan Rakyat memegang kekuasaan membentuk undangundang." Undang-undang itu selalu berisi segala sesuatu yang menyangkut kebijakan kenegaraan untuk melaksanakan amanat undang-undang dasar di bidang-bidang tertentu yang memerlukan persetujuan bersama antara Presiden dan Dewan Perwakilan Rakyat. ${ }^{44}$ Oleh karena itu, ditentukan oleh Pasal 20 ayat (2) bahwa "Setiap rancangan undang-undang itu dibahas oleh Dewan Perwakilan Rakyat dan Presiden untuk mendapat persetujuan bersama." Pada ayat (4)nya menentukan, "Presiden mengesahkan rancangan undangundang yang telah disetujui bersama untuk menjadi undang-undang." Produk undangundang ini merupakan bentuk hukum peraturan yang paling tinggi statusnya di bawah Undang Undang Dasar. ${ }^{45}$

Sabdaraja, Sabdatama, dan Dhawuhraja adalah titah Sultan sebagai raja Yogyakarta dan hanya mengikat untuk internal keraton saja. Tetapi, ketika isi dari Sabdaraja, Sabdatama, dan Dhawuhraja tersebut mengatur terkait dengan sistem pemerintahan, maka Sabdaraja, Sabdatama, dan Dhawuhraja tidak dikenal dalam peraturan perundang-undangan maupun pengambilan keputusan pemerintahan serta Sabatama, Sabdaraja dan Dhawuhraja bukan sebagai sumber hukum baik materil maupun formal. Jadi Sabdaraja, Sabdatama, dan Dhawuhraja tidak bisa diuji dalam perspektif hukum nasional, yang bisa mengkaji adalah kalangan internal keraton itu sendiri. Oleh karena itu, Sabdaraja, Sabdatama, dan Dhawuhraja tidak berisi urusan pemerintahan. Sultan juga tidak boleh menyalahgunakan Sabdaraja, Sabdatama dan Dhawuhraja untuk mengatur pemerintahan. Karena menurut peneliti, dengan pernyataan Sultan yang demikian seolah-olah Sultan menempatkan Sabdatama, Sabdaraja, dan Dhawuhraja berada di atas UUK DIY, sehingga hal ini jelas telah bertentangan dengan teori hierarki peraturan perundang-undangan yang ada di Indonesia. Kalau Sultan ingin mengatur pemerintahan, maka yang berlaku adalah UUK DIY dan Peraturan-Peraturan Daerah Keistimewaan DIY karena pengakuan negara terhadap status keistimewaan Yogyakarta telah dirumuskan dalam UUD NRI Tahun 1945 dan telah diperjelas dalam UUK DIY.

${ }^{43}$ Maria Farida Indrati Soeprapto, Ilmu Perundang-Undangan: Dasar-dasar dan Pembentukannya, Kanisius, Yogyakarta, 1998, hlm. 169.

${ }^{44}$ Jimly Asshiddiqie, Pengantar Ilmu Hukum Tata Negara, Rajawali Pers, Jakarta, 2013, hlm. 165.

${ }^{45}$ Ibid. 


\section{Penutup}

Berdasarkan uraian analisis di atas, dapat ditarik kesimpulan sebagai berikut: Pertama, Sabdatama dan Sabdaraja yang diterbitkan oleh Sultan Hamengku Buwono X pada dasarnya telah bertentangan dengan UU No. 13 Tahun 2012 tentang Keistimewaan DIY. Diterbitkannya Sabdatama dan Sabdaraja sebagai bentuk inkonsistensi dari sikap Sri Sultan Hamengku Buwono $\mathrm{X}$ terhadap keinginan beliau ketika dahulu mengajukan pembentukan RUUK DIY kepada Pemerintah untuk status DIY. Kedua, Sabdatama dan Sabdaraja bukan merupakan sumber hukum tata negara, baik formal maupun materiil. Karena isi dari Sabdatama dan Sabdaraja tersebut hingga saat ini belum sepenuhnya diakui oleh Pemerintah DIY dan masyarakat Yogyakarta sehingga tidak memiliki legitimasi apapun dalam mengatur pemerintahan Yogyakarta. Sabdatama dan Sabdaraja hanya berlaku internal keraton Yogyakarta. Dengan demikian, apabila masyarakat Yogyakarta belum dapat menerima isi dari Sabdatama dan Sabdaraja maka tidak dapat dijadikan sumber hukum untuk merevisi UUK.

Untuk itu, maka Sri Sultan HB X harus meminta pendapat rakyat apakah rakyat Yogyakarta menghendaki perubahan UUK seperti isi dari Sabdatama dan Sabdaraja atau tetap seperti apa yang sekarang sudah ditentukan dalam UUK. Keistimewaan yang dimiliki oleh DIY bukannya tanpa batasan-batasan konstitusional apalagi hanya ditentukan oleh satu orang, tetapi pemerintahan demokratis menghendaki dukungan masyarakat untuk menjaga dan menegakkannya agar tidak keluar dari koridor UUD NRI Tahun 1945 khususnya dalam Pasal 18B ayat (1).

\section{Daftar Pustaka}

Athar Hasimin, Muhammad, "Pengaruh Nilai-nilai Tasawuf dalam Tata Negara Adat (Studi Konstitusi Martabat Tujuh Kesultanan Buton)”, Fakultas Hukum UII, yogyakarta, 2009.

Farida Indrati Soeprapto, Maria, Ilmu Perundang-Undangan: Dasar-dasar dan Pembentukannya, Kanisius, Yogyakarta, 1998.

Hamidi, Jazim \& Mustafa Lutfi, Dekonstruksi Hukum Pengawasan Pemerintahan Daerah (The Turning Point of Local Autonomy), UB Press, Malang, 2011.

Huda, Ni’matul, Hukum Tata Negara Indonesia, PT Rajagrafindo Persada, Jakarta, 2006.

, Desentralisasi Asimetris dalam NKRI: Kajian Terhadap Daerah Istimewa, Daerah Khusus, dan Otonomi Khusus, Nusa Media, Bandung, 2014. 
"Implikasi Sabdaraja dan Dhawuhraja terhadap UU No. 13 Tahun 2012 Tentang Keistimewaan DIY" disampaikan dalam acara Pengajian dan Buka Bersama dengan Tema "Membaca Masa Depan Keistimewaan DIY Di Tengah-tengah Arus Demokratisasi" yang diselenggarakan oleh LBH KAHMI DIY pada hari Selasa, 27 Juni 2015.

Kusnardi, Moh., dan Harmaily Ibrahim, Pengantar Hukum Tata Negara Indonesia, Sinar Bakti, Jakarta, 1988.

Manan, Bagir, Konvensi Ketatanegaraan, FH UII Press, Yogyakarta, 2006.

Salman Soemadiningrat, Otje, Rekonseptualisasi Hukum Adat Kontemporer, PT. Alumni, Bandung, 2002.

Soejamto, Daerah Istimewa Dalam Negara Kesatuan Republik Indonesia, dalam Suryo Sakti Hadiwijoyo, Menggugat Keistimewaan Yogyakarta: Tarik Ulur Kepentingan, Konflik Elit, dan Isu Perpecahan, Pinus Book Publisher, Yogyakarta, 2009.

Soimin, Pembentukan Peraturan Perundang-Undangan Negara di Indonesia”, UII Press, Yogyakarta, 2010.

Undang-Undang Dasar Negara Republik Indonesia Tahun 1945.

Undang-Undang Nomor 23 Tahun 2014 tentang Pemerintahan Daerah.

Undang-Undang Nomor 13 tahun 2012 tentang Keistimewaan Daerah Istimewa Yogyakarta.

Undang-Undang Nomor 12 Tahun 2011 tentang Pembentukan Peraturan PerundangUndangan.

Putusan MK Nomor 072-073/PUU-11/2004 tentang tafsir makna demokratis yang termuat dalam Pasal 18 ayat (4) UUD NRI Tahun 1945.

http://web.jogjaprov.go.id/pemerintahan/situs-tautan/view/ diakses pada 3 Juni 2015.

http://krjogja.com/read/251505/inilah-sabdatama-sultan-pada-10-mei-2012.kr diakses pada 20 Desember 2015.

http://news.liputan6.com/read/2228868/ini-isi-sabda-raja-dan-dawuh-raja?p=1 diakses pada 20 Desember 2015.

http://nasional.tempo.co/read/news/2015/05/07/058664258/hari-ini-adik-sultan-penolaksabda-raja-tunggu-masukan diakses pada 26 Desember 2015.

http://sorotjogja.com/penolakan-bertebaran-sejumlah/ diakses pada 26 Desember 2015.

http://bayudardias.staff.ugm.ac.id/2015/05/06/sabdatama-sabdaraja-sultan hamengkubuwono-x/ diakses pada 18 Januari 2016.

http://kbbi.web.id/ diakses pada 9 Juni 2015.

http://brainly.co.id/tugas/1035580 diakses pada 9 Juni 2015.

Hasil wawancara peneliti dengan Gusti Bendoro Pangeran Haryo Yudhaningrat sebagai adik dari Sultan Hamengku Buwono X di Kantor Gubernur Provinsi DIY pada 14 Januari 2016. 